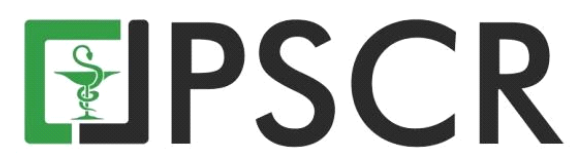

\title{
Efektivitas Komposisi Polivynil Alkohol, Propilenglikol dan Karbomer Terhadap Optimasi Masker Gel Peel-off Nano Ekstrak Daging Buah Labu Kuning (Cucurbita maxima D)
}

\author{
Istianatus Sunnah*, Agitya Resti Erwiyani, Nyai Melati Pratama dan Krismelinda \\ Octavia Yunisa
}

Program Studi Farmasi, Universitas Ngudi Waluyo Ungaran

*email korespondensi: istihizna@yahoo.com

\begin{abstract}
Abstrak: Masker gel peel-off merupakan salah satu bentuk sediaan kosmetika perawatan, yang bertujuan untuk mengangkat kotoran yang menempel di kulit wajah. Komposisi basis dalam formulasi masker gel peel-off sangat menentukan respon sifat fisik dan stabilitas sediaan berupa $\mathrm{pH}$, daya sebar, waktu kering dan viskositas. Permasalahan yang sering dialami dalam formulasi masker gel peel- off yaitu waktu kering dan viskositas yang tidak memenuhi standar. Sehingga, penelitian ini bertujuan untuk optimasi formula dalam sediaan masker gel peel-off nanopartikel ekstrak labu kuning, untuk mendapatkan formula optimal basis PVA, propilenglikol dan karbomer yang memiliki stabilitas fisik sesuai persyaratan. Design expert digunakan sebagai software untuk menentukan formula optimal menggunakan metode D-optimal, dengan respon sifat fisik $\mathrm{pH}$, daya sebar, waktu kering, viskositas dan sentrifugasi. Formula optimal yang digunakan adalah formula dengan nilai desirability mendekat 1. Ekstrak daging labu kuning dibuat dalam ukuran nanopartikel dengan rasio kitosan: Na TPP: Ekstrak (5:1:1) kemudian dilakukan pengukuran transmittan dan ukuran partikel (PSA). Hasil optimasi nanopartikel didapatkan ukuran partikel ekstrak 256,4 nm dengan nilai transmittan 99,88\%. Optimasi formula diperoleh komposisi formula optimal PVA $(3,951 \mathrm{~g})$, karbomer $(0,576 \mathrm{~g})$ dan propilenglikol $(5,473 \mathrm{~g})$ memberikan respon sifat fisik berupa $\mathrm{pH}(5,99)$, daya sebar $(5 \mathrm{~cm})$, waktu kering $(6,10$ menit) dan viskositas (9252 cps). Uji $\mathrm{T}$ menunjukkan tidak terdapat perbedaan bermakna antara hasil optimasi berdasarkan software design expert dengan uji konfirmasi formula optimal (p 0,388>0,5).
\end{abstract}

Kata kunci: Optimasi; Design expert; Masker gel peel-off; Ekstrak nanopartikel

Abstract. Efectivity Compotition of PVA, Propylene Glycole and Carbomer to Optimization of Nano Extraxt Pumkins (Cucurbita maxima D) Peel Off Mask Gel. The base composition in a peel-off gel mask formulation largely determines the response of physical properties and stability of the preparation in the form of $\mathrm{pH}$, spreadability, dry time and viscosity. Problems that are often experienced in peel off gel mask formulations are dry time and viscosity which do not meet the standards. The optimization of nanoparticle extract pumpkin in peel-off gel mask form can improve the lack of physical properties. Optimized base components are PVA, Carbomer and propylenglycol. Design experts are used as software to determine the optimal formula using the D-optimal method, with desirability values approaching 1. Pumpkin extract is made in nanoparticle size to facilitate transport into skin tissue and remain in the tissue when flushing masks. The results of particle size in nanoparticle optimization obtained of $256.4 \mathrm{~nm}$ with transmittance of $99.88 \%$. Optimization of the formula obtained by the composition of the optimal formula PVA $(3.951 \mathrm{~g})$, carbomer $(0.576 \mathrm{~g})$ and 
propylenglycol $(5.473 \mathrm{~g})$ gave responses to physical properties in the form of $\mathrm{pH}(5.99)$, spreadability $(5 \mathrm{~cm})$, dry time $(6.10$ minutes) and viscosity $(9252 \mathrm{cps})$. T test showed no significant difference between the results of optimization based on expert design software with the optimal formula confirmation test ( $\mathrm{p} 0.388>0.5)$.

Keywords: Optimization; Design expert; Peel-off gel mask; Nanoparticle extract

\section{Pendahuluan}

Kebersihan kulit muka merupakan hal yang wajib dilakukan oleh semua orang. Terdapat beberapa sediaan yang digunakan sebagai pembersih muka seperti krim pembersih, face toner maupun masker. Kosmetika herbal saat ini diminati karena menggunakan bahan alam, yang jarang memiliki efek samping terhadap kulit seperti bahan kimia atau sintetis lain (Pal et al., 2017). Masker wajah merupakan formula paling mudah digunakan diantara sediaan tersebut. Masker gel peel-off merupakan sediaan masker wajah dalam bentuk gel yang bening, basisnya secara umum memiliki komposisi PVA, propilenglikol dan karbomer. Prinsip kerja dari gel ini yaitu menarik kotoran pada bagian wajah setelah diaplikasikan selama kurang lebih 10-15 menit. Permasalahan yang sering terjadi pada formulasi masker gel peel-off adalah waktu kering tidak sesuai dengan persyaratan, konsistensi terlalu cair atau kental, sehingga menyebabkan penyebaran sediaan tidak sempurna. Konsentrasi Etanol berperan penting dalam menentukan waktu kering masker (Sulastri \& Chaerunisaa, 2016). Untuk itu perlu dilakukan optimasi dengan basis PVA, propilenglikol dan karbomer supaya menghasilkan respon daya sebar, $\mathrm{pH}$, daya lekat, sentrifugasi serta waktu kering yang baik.

Labu kuning memiliki kandungan senyawa metabolit berupa flavonoid yang memiliki fungsi sebagai antioksidan dan antiaging. Selama ini labu kuning hanya dimanfaatkan sebagai bahan pangan saja. Berdasarkan penelitian, daging labu kuning memiliki daya antioksidan yang kuat (Rikhana, 2018). Hasil penelitian (Salehi et al., 2019) menjelaskan bahwa Cucurbita spp atau yang sering disebut sebagai pumpkins memiliki aktivitas farmakologi sebagai antioksidan, antimikroba, anti kanker serta anti diabetes karena kandungan fitokimia seperti protein, fitosterol, asam lemak tak jenuh, tokoferol dan karoteoid. Penelitian sebelumnya menggunakan ekstrak biji labu kuning sebagai masker gel peel-off memberikan hasil, waktu kering belum memenuhi standar (Sunnah, et al.,2018). Waktu kering yang dihasilkan dari optimasi masker gel peel-off dengan basis PVA dan HPMC, berkisar antara 3050 menit. Hal ini akan menyebabkan kurangnya kenyamanan dalam pemakaian, karena harus menunggu waktu yang lama untuk bisa dilepas dari wajah dan efektivitas berkurang. Sehingga, penelitian ini bertujuan untuk optimasi formula sediaan masker gel peel-off nanopartikel ekstrak labu kuning, untuk mendapatkan formula optimal basis dengan komposisi PVA, propilenglikol dan karbomer. Polivinyil alcohol (PVA) berfungsi sebagai 
agen pembentuk film, karbomer sebagai penentu viskositas dari gel (Beringhs, et al., 2013). Penggunaan propilenglikol dalam sediaan kosmetik untuk pembentuk lapisan plastik (Rowe et al.,2009).

\section{Bahan dan Metode}

\subsection{Bahan dan alat}

Buah labu kuning diperoleh dari Desa Getasan Kab. Semarang, etanol 96\% (Brataco, kualitas farmasetika), kitosan (kualitas farmasetika), Na TPP (kualitas farmasetika), PVA (Merck, kualitas farmasetika), propilenglikol (Brataco, kualitas farmasetika), karbomer (kualitas farmasetika), TEA (Brataco, kualitas farmasetika). Alat yang digunakan Rotary evaporator, thermostatic water bath DHH-88, timbangan analitik Ohaus, magnetic stirer thermo CMMr, PSA Malvern, indikator universal $\mathrm{pH}$, satu set alat pengukur daya sebar, viskometer brookfield DV2T, alat sentrifugasi PLC series.

\subsection{Ekstraksi}

Ekstraksi daging buah labu kuning menggunakan pelarut etanol $96 \%$ supaya kandungan senyawa flavonoid baik polar maupun non-polar dapat tersari secara sempurna. Maserasi dilakukan selama 5 hari, ekstrak dipekatkan dengan rotary evaporator pada suhu $60^{\circ} \mathrm{C}$.

\subsection{Nano partikel ekstrak daging buah labu kuning}

Pembuatan nano partikel ekstrak daging buah labu kuning menggunakan metode gelasi ionik dengan perbandingan kitosan: Na TPP: ekstrak (5:1:1) dan pengukuran karakterisasi partikel nano yaitu \% transmittan dan Particle Size Analyzer (PSA).

\subsection{Optimasi formula masker gel peel- off}

Komposisi basis terdiri dari PVA, propilenglikol dan karbomer, dioptimasi menggunakan software Design Expert dengan metode D-optimal dengan jumlah total basis yang dioptimasi sebanyak 10 gram. PVA yang akan diformulasikan menggunakan aras rendah $1 \%$ dan aras tinggi $6 \%$, karbomer aras rendah $0,5 \%$ dan aras tinggi $2 \%$, sedangkan propilenglikol aras rendah $10 \%$ dan aras tinggi 15\% (Tabel 1).

Tabel 1. Aras Rendah dan aras tinggi komposisi basis optimasi formula masker gel peel-off eksktrak daging buah labu kuning (Cucurbita maxima $D$ ).

\begin{tabular}{ccc}
\hline Basis & Aras rendah (\%) & Aras tinggi (\%) \\
\hline PVA & 1 & 6 \\
Karbomer & 0,5 & 2 \\
Propilenglikol & 10 & 15 \\
\hline
\end{tabular}


Sebanyak 16 run (Tabel 4) formula diuji parameter respon meliputi $\mathrm{pH}$, daya sebar, viskositas, waktu kering dan sentrifugasi. Setelah dilakukan pengujian, akan didapatkan formula optimal berdasarkan software design expert. Uji konfirmasi dilakukan untuk membandingkan hasil pengujian respon yang diperoleh berdasarkan software dengan uji konfirmasi.

\subsection{Formulasi masker gel peel-off eksktrak daging buah labu kuning}

Formula utama yang digunakan sebagai masker gel peel-off terdiri dari nano ekstrak daging labu kuning sebanyak $1 \%$, PVA, karbomer, propilenglikol, TEA dan Akuades (Tabel 2). Polivinil alkohol ditambahkan akuades kemudian dipanaskan, diaduk sampai homogen dan larutan menjadi bening (Birck et al.,2014). Karbomer dilarutkan dengan akuades hingga mengembang dan terlarut sempurna, ditambahkan TEA. Sedikit demi sedikit ditambahkan propilenglikol sampai homogen. Nano ekstrak yang telah dilarutkan dengan air, ditambahkan ke dalam basis sampai $100 \mathrm{~g}$.

Tabel 2. Formula masker gel peel -off ekstrak daging labu kuning (Cucurbita maxima D).

\begin{tabular}{cc}
\hline Bahan & Konsentrasi \\
\hline Nano Ekstrak daging labu kuning & $1 \%$ \\
PVA & Optimasi \\
Karbomer & Optimasi \\
Propilenglikol & Optimasi \\
TEA & $2 \%$ \\
Aqua ad & $100 \%$ \\
\hline
\end{tabular}

Konsentrasi $1 \%$ diambil dari dosis ekstrak daging buah labu kuning berdasarkan penelitian sebelumnya dikonversi ke tikus dengan berat 200gram sebesar 40mg/200 gram per hari. Konversi dalam dosis sekali pakai manusia didapatkan 1,2 gram (Sharma et al., 2013)

\subsection{Uji parameter sifat fisik masker gel peel-off}

\subsubsection{Uji pH}

Alat $\mathrm{pH}$ meter dicelupkan ke dalam sediaan masker yang telah diencerkan. $\mathrm{pH}$ sediaan topikal harus sesuai dengan $\mathrm{pH}$ kulit yaitu 4,5-6,5.

\subsubsection{Uji daya sebar}

Sediaan masker gel sebanyak 500 mg diletakkan di atas kaca uji daya sebar, kemudian ditutup dengan kaca transparan dan diberikan beban sampai 150 gram. Daya sebar diperoleh dengan cara menghitung diameter penyebaran setelah diberikan beban selama 1 menit. 


\subsubsection{Uji viskositas}

Viskositas masker gel peel-off diukur menggunakan Viskometer Brookfield spindle no.4. Kecepatan diatur $50 \mathrm{rpm}$.

\subsubsection{Uji waktu kering}

Sebanyak 1gram masker gel peel-off dioleskan secara merata di atas punggung tangan, kemudian diamati waktu pengeringan sampai masker dapat dilepas. Waktu kering masker yang baik antara 15-30 menit.

\subsubsection{Uji sentrifugasi}

Sebanyak 10gram masker gel, dimasukkan ke dalam tabung sentrifugasi, kemudian diputar dengan kecepatan 5000 rpm selama 30 menit. Parameter yang diamati adalah terbentuknya buih dan penurunan volume cairan masker gel.

\subsection{Analisa data}

Data hasil optimasi dan hasil konfirmasi sifat fisik diuji menggunakan t-test untuk membandingkan perbedaan bermakna antara keduanya.

\section{Hasil dan Pembahasan}

\subsection{Ekstraksi daging buah labu kuning}

Hasil ekstraksi diperoleh rendemen sebesar 47,85\% dengan karakteristik ekstrak berwarna coklat, kental dan berbau manis. Proses ekstraksi yang dilakukan sangat efektif karena rendemen yang dihasilkan telah memenuhi persyaratan yaitu lebih dari $10 \%$. Rendemen yang tinggi, dimungkinkan banyak senyawa kimia yang dapat tersari di dalam ekstrak.

\subsection{Nano ekstrak daging buah labu kuning}

Partikel nano ekstrak daging buah labu kuning yang dihasilkan memiliki karakteristik sesuai dengan yang diinginkan. Perbandingan kitosan: Na TPP: ekstrak (5:1:1) menghasilkan nilai transmittan sebesar 99,88\% dengan ukuran partikel sebesar 256,4 nm (Tabel 3).

Tabel 3. Hasil karakterisasi nanopartikel ekstrak daging buah labu kuning (Cucurbita maxima $D$ ) menggunakan pelarut etanol $96 \%$

\begin{tabular}{cccc}
\hline Sampel & $\begin{array}{c}\text { Ukuran } \\
\text { Partikel (nm) }\end{array}$ & \% transmittan & Organoleptis \\
\hline Ekstrak Daging Labu Kuning & 256,4 & 99,88 & Larutan jernih \\
\hline
\end{tabular}

Secara fisik, bentuk nano partikel tidak dapat diamati secara visual, tetapi dengan terbentuknya larutan yang jernih kemudian dibuktikan dengan nilai transmittan, PSA serta morfologinya (Tabel 3). Indikator awal terbentuknya nanopartikel adalah transmitan yang berhubungan dengan indeks bias serta celah energi antar partikel. Indeks bias dan celah 
energi antar partikel dipengaruhi oleh ukuran partikel senyawa. Ukuran partikel kecil maka indeks bias akan berkurang, sehingga celah energi pada partikel menjadi lemah. Larutan akan semakin transparan dan jernih. Pengaruh ini yang akan menyebabkan efek transmitasi menjadi meningkat. Formulasi yang memiliki transmitasi mendekati 100\%, akan membentuk sifat transparan yang bagus (Abed \& Al-rashid, 2018).

Partikel dinyatakan dalam bentuk nano apabila memiliki ukuran dibawah $1000 \mathrm{~nm}$. Target ukuran nanopartikel ekstrak labu kuning yang dihasilkan telah terpenuhi yaitu 256,4 $\mathrm{nm}(<1 \mu \mathrm{m})$ tergambar dalam Tabel 3. Kosmetika dalam ukuran nano partikel merupakan kosmetika yang mulai trend saat ini karena dengan ukuran nano mampu meningkatkan masuknya partikel ke dalam jaringan target dan mampu memberikan pelepasan obat secara terkontrol (Goyal et al., 2016). Selain itu, zat aktif dalam ukuran nano, akan mencegah partikel tersebut hilang atau lepas apabila sediaan mengalami pembilasan atau pencucian (Draelos \& Thaman, 2006).

\subsection{Optimasi masker gel peel-off nano ekstrak daging labu kuning}

Dalam menentukan formula optimal, 16 run formula pada Tabel 4 dilakukan uji sifat fisik meliputi $\mathrm{pH}$, daya sebar, waktu kering, viskositas dan sentrifugasi (Tabel 4). Hal ini dilakukan untuk menganalisis efektivitas dari komposisi PVA, karbomer dan propilenglikol terhadap respon sifat fisik tersebut.

Tabel 4. Hasil Run Formula Masker Gel Peel -Off ekstrak daging buah labu kuning (Cucurbita maxima D) berdasarkan Software Design Expert dengan metode Doptimal.

\begin{tabular}{ccccccccc}
\hline Run & $\begin{array}{c}\text { PVA } \\
(\mathbf{g})\end{array}$ & $\begin{array}{c}\text { Karbomer } \\
(\mathbf{g})\end{array}$ & $\begin{array}{c}\text { Propilen } \\
\text { Glikol (g) }\end{array}$ & pH & $\begin{array}{c}\text { Daya } \\
\text { Sebar } \\
(\mathbf{c m})\end{array}$ & $\begin{array}{c}\text { Viskositas } \\
(\mathbf{c p s})\end{array}$ & $\begin{array}{c}\text { Waktu } \\
\text { Kering } \\
(\mathbf{m e n i t})\end{array}$ & $\begin{array}{c}\text { Sentri } \\
\text { Fugasi }\end{array}$ \\
\hline 1 & 4,75 & 0,50 & 4,75 & 6 & 5,3 & 11150 & 11,27 & 1 \\
2 & 2,00 & 2,00 & 6,00 & 5 & 5,2 & 10780 & 10,36 & 1 \\
3 & 6,00 & 0,50 & 3,50 & 6 & 5,2 & 5964 & 16,22 & 1 \\
4 & 2,75 & 1,25 & 6,00 & 6 & 5,0 & 12000 & 14,41 & 1 \\
5 & 6,00 & 0,50 & 3,50 & 6 & 5,5 & 9900 & 20,35 & 1 \\
6 & 3,50 & 0,50 & 6,00 & 6 & 5,4 & 9900 & 7,29 & 1 \\
7 & 5,19 & 0,88 & 3,94 & 6 & 5,2 & 9,564 & 12,39 & 1 \\
8 & 4,00 & 2,00 & 4,00 & 6 & 5,0 & 10720 & 6,28 & 1 \\
9 & 6,00 & 2,00 & 2,00 & 6 & 5,5 & 10620 & 3,32 & 1 \\
10 & 5,19 & 1,62 & 3,18 & 5 & 5,0 & 11140 & 16,04 & 1 \\
11 & 3,57 & 1,25 & 5,19 & 5 & 5,0 & 9288 & 9,28 & 1 \\
12 & 3,50 & 0,50 & 6,00 & 5 & 5,0 & 9688 & 7,36 & 1 \\
13 & 6,00 & 2,00 & 2,00 & 5 & 5,5 & 10900 & 3,36 & 1 \\
14 & 2,00 & 2,00 & 6,00 & 6 & 5,0 & 10320 & 10,40 & 1 \\
15 & 6,00 & 1,25 & 2,75 & 5 & 5,0 & 11270 & 13,59 & 1 \\
16 & 4,00 & 2,00 & 4,00 & 6 & 5,2 & 10040 & 11,27 & 1 \\
\hline
\end{tabular}




\subsubsection{Uji pH}

Hasil uji $\mathrm{pH}$ pada ke 16 run formula menunjukkan $\mathrm{pH}$ sesuai dengan persyaratan $\mathrm{pH}$ kulit yaitu 4,5-6,5. Komposisi PVA (A), karbomer (B) maupun propilenglikol (C) memiliki kemampuan dalam meningkatkan $\mathrm{pH}$, tetapi yang berperan penting dalam peningkatan $\mathrm{pH}$ paling tinggi yaitu karbomer. Karbomer merupakan gelling agent yang bagus karena memiliki sifat bioadhesiv dan transparan pada pH 6-8, (Dewi \& Saptarini, 2016). Pada Gambar 1, menunjukkan bahwa semakin tinggi karbomer, ditandai dengan area warna merah, akan menyebabkan peningkatan $\mathrm{pH}$. Hal ini sesuai dengan persamaan respon yang dihasilkan design expert sebagai berikut: $\mathrm{Y}=0,5518(\mathrm{~A})+7,28655(\mathrm{~B})+0,48386(\mathrm{C})-0,96806(\mathrm{~A})(\mathrm{B})+$ $0,077367(\mathrm{~A})(\mathrm{C})-0,79673(\mathrm{~B})(\mathrm{C})$. Interaksi antara ketiga basis menyebabkan terjadinya penurunan $\mathrm{pH}$ menjadi semakin asam, tetapi masih memiliki rentang $\mathrm{pH}$ antara 4,5-6,5. Sediaan yang memiliki $\mathrm{pH}$ sesuai dengan $\mathrm{pH}$ kulit yaitu 4,5-6,5 maka mudah sekali untuk diterima dan diabsorpsi oleh kulit, sehingga akan memberikan efek optimal (Zhelsiana et al., 2016). Kondisi pH masker gel peel off terlalu asam akan menyebabkan terjadinya iritasi kulit (Rahmawanty, et al., 2015).

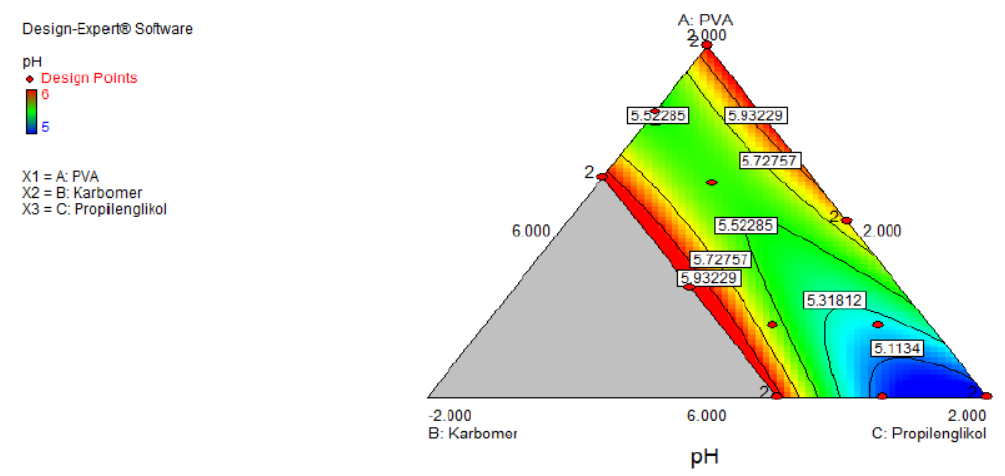

Gambar 1. Contour plot respon $\mathrm{pH}$ pada ke 16 run formula Masker Gel Peel -Off ekstrak daging buah labu kuning (Cucurbita maxima $D$ ).

\subsubsection{Daya sebar}

Daya sebar sangat mempengaruhi efektifitas sediaan topikal karena menunjukkan kemampuan sediaan untuk mudah dioleskan dan menyebar pada area kulit. Pada formulasi ini memiliki bahan yang berpengaruh terhadap daya sebar yaitu propilenglikol dan karbomer. Selain sebagai humectant, propilenglikol dengan konsistensi cair, memiliki pengaruh terhadap daya sebar (Daood et al., 2019), tetapi karbomer paling berpengaruh terhadap daya sebar diantara keduanya. Gambar 2, menunjukkan bahwa komponen karbomer memiliki pengaruh besar terhadap daya sebar. Sesuai dengan sifat fisikokimianya, karbomer akan membentuk gel dengan kekentalan yang tinggi. Akan tetapi daya penyebaran masker yang dihasilkan masih sesuai dengan standar yaitu $5-7 \mathrm{~cm}$ (Garg, A., et al., 2002). Hal ini dipengaruhi oleh adanya interaksi antara PVA dengan karbomer yang mampu menurunkan kekentalan sediaan. Persamaan 
respon yang dihasilkan juga mendukung pernyataan tersebut $\mathrm{Y}=0,68679(\mathrm{~A})+4,08369(\mathrm{~B})+$ $0,66355(\mathrm{C})-0,47456(\mathrm{~A})(\mathrm{B})-0,03354(\mathrm{~A})(\mathrm{C})$.

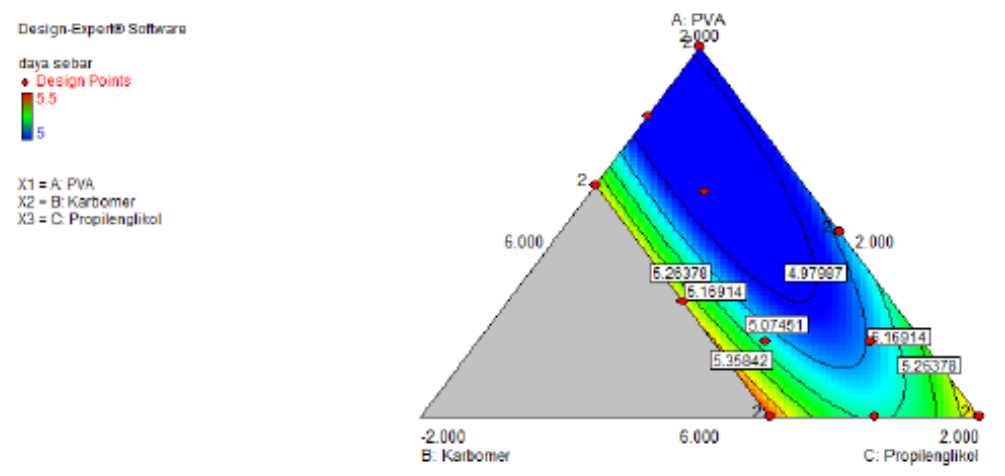

Gambar 2. Contour plot respon daya sebar formula Masker Gel Peel -Off ekstrak daging buah labu kuning (Cucurbita maxima D).

\subsubsection{Waktu kering}

Optimasi masker gel peel-off dilakukan untuk memperbaiki kekurangan dari formula optimasi sebelumnya yaitu waktu kering yang relatif lebih lama. Waktu kering yang dipersyaratkan antara 15-30 (Budiman et al., 2017). Hasil optimasi menggunakan design expert metode $D$-optimal terdapat pada Persamaan 1.

$\mathrm{Y}=+3,65793(\mathrm{~A})-65,94090(\mathrm{~B})-2,02521(\mathrm{C})+6,50334(\mathrm{~A})(\mathrm{B})-0,11239(\mathrm{~A})(\mathrm{C})+10,22799(\mathrm{~B})(\mathrm{C})$

Persamaan 1. Persamaan hasil optimasi menggunakan design expert metode D-optimal formula masker gel peel -off ekstrak daging buah labu kuning (Cucurbita maxima D). Keterangan: respon waktu kering (Y), PVA (A), Karbomer (B) dan Propilenglikol (C).

Polivynil alkohol berpengaruh terhadap lama waktu kering sediaan masker gel. Sedangkan karbomer dan propilenglikol menurunkan waktu kering sediaan. Propilenglikol merupakan humectan yang berfungsi sebagai penghidrasi kulit juga sebagai pelembab kulit. Pemilihan propilenglikol sebagai humectan dalam formula ini, karena mampu melembabkan kulit wajah juga mampu menurunkan waktu kering sediaan dengan meretakkan PVA sebagai lapisan film (Jayronia, 2016). Hal ini ditegaskan dengan gambar contour plot (3), terlihat bahwa area PVA memiliki warna hijau, merupakan warna yang paling dominan yang berarti bahwa PVA berperan penting dalam penentuan waktu kering. Run formula yang dihasilkan pada Tabel 4, menunjukkan hal yang sama. Kombinasi karbomer dan propilenglikol dalam sediaan mampu menurunkan waktu kering. Formula 9 dan 13 memiliki konsentrasi karbomer dan propilenglikol sama dengan jumlah PVA 2 kali lipat. Waktu kering pada formula tersebut terlalu cepat yaitu sekitar 3 menit. Formula 3, 5 dan 10, memiliki konsentrasi karbomer dan propilenglikol lebih rendah dibandingkan dengan PVA, sehingga waktu kering yang dihasilkan lebih lama yaitu 16- 20 menit. PVA merupakan polimer yang mampu membentuk 
lapisan film yang kuat dan gelling agent dengan waktu kering yang sangat cepat. Dengan konsentrasi PVA relatif tinggi, maka masker gel peel-off lebih cepat mengering (Rowe, et al., 2009).
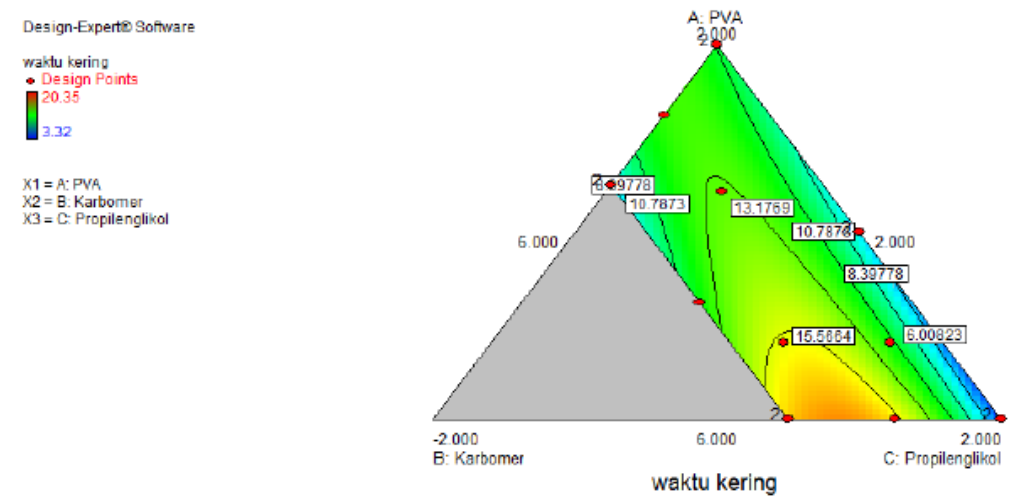

Gambar 3. Contour plot respon waktu kering formula Masker Gel Peel -Off ekstrak daging buah labu kuning (Cucurbita maxima D).

\subsubsection{Viskositas}

Viskositas masker memiliki hubungan dengan daya sebar, semakin kental suatu formula, akan memiliki daya sebar yang lebih kecil. Gambar 4, menunjukkan bahwa PVA dan propilenglikol berperan dalam meningkatkan kekentalan masker. Interaksi antara PVA dengan karbomer menyebabkan peningkatan viskositas masker. Penambahan propilenglikol yang memiliki konsistensi lebih cair, maka viskositas sediaan masker mengalami penurunan. Propilenglikol memiliki viskositas rendah, sehingga mampu mengurangi kekentalan masker (Andini, Yusriadi, \& Yuliet, 2017).
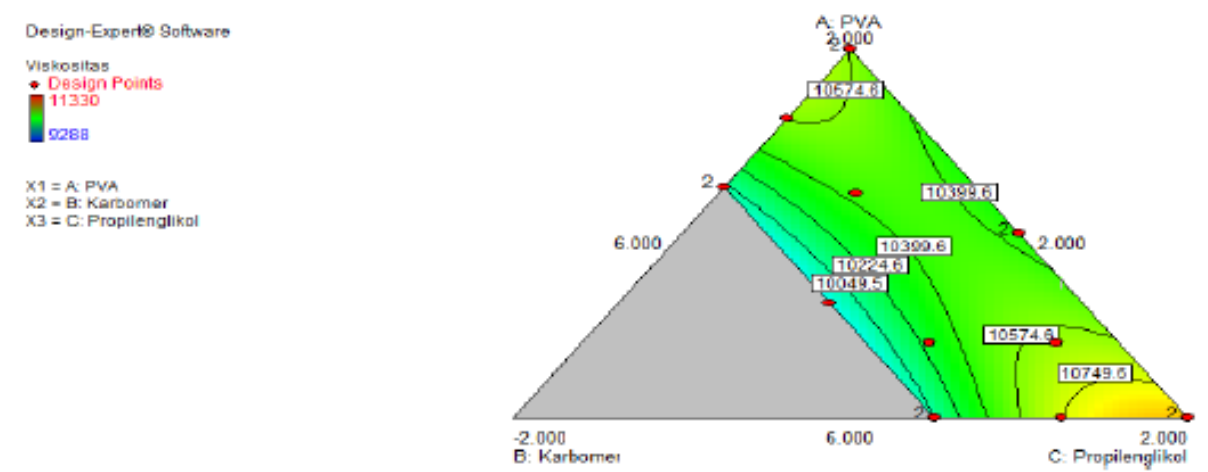

Gambar 4. Contour plot respon viskositas formula masker gel peel -off ekstrak daging buah labu kuning (Cucurbita maxima D).

Interaksi tersebut dapat dilihat pada persamaan respon berikut: $\mathrm{Y}=+1158,54808$ (A) 2646,2157(B) +1172,23026 (C) + 518,46353(A)(B)- 98,18754 (A)(C) + 467,69605 (B)(C). Sebagai humektan, propilenglikol berperan menjaga kelembapan kulit dengan cara mengurangi penguapan kadar air pada kulit (Rowe et al., 2009). Propilenglikol memiliki afinitas tinggi dalam menahan dan menarik air di lingkungannya, sehingga bersifat higroskopis (Reveny, et al., 2016). 


\subsubsection{Sentrifugasi}

Sentrifugasi merupakan salah satu parameter yang menunjukkan stabilitas sediaan masker. Komposisi ketiganya baik PVA, karbomer dan propilenglikol memiliki pengaruh yang sama dalam sentrifugasi (Gambar 5) dengan diagram contour plot berwarna kuning merata. Hasil sentrifugasi menunjukkan setelah diputar dengan kecepatan 5000 rpm, sediaan masker gel tetap homogen. Kemampuan masker gel untuk tetap homogen menunjukkan bahwa sediaan akan tetap stabil selama penyimpanan.
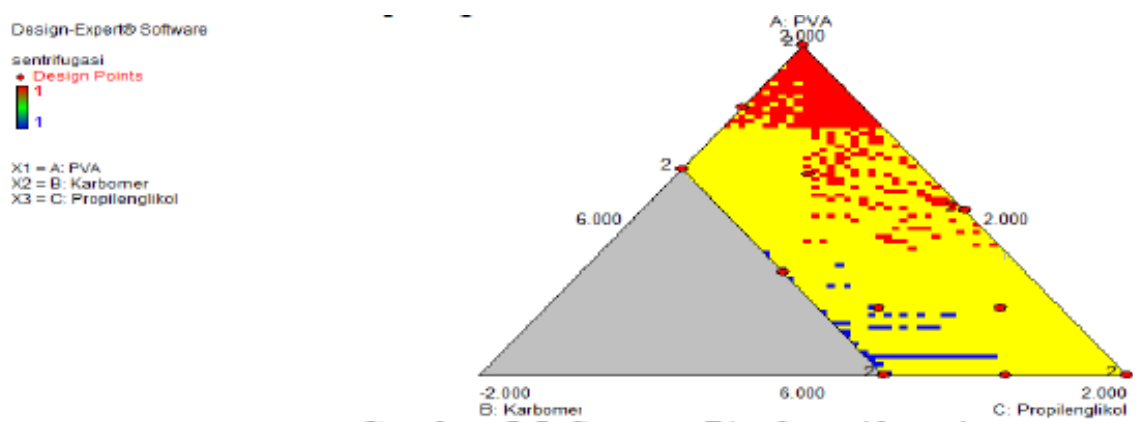

Gambar 5. Contour plot respon sentrifugasi formula masker gel peel -off ekstrak daging buah labu kuning (Cucurbita maxima D).

\subsubsection{Penentuan formula optimal dan uji konfirmasi}

Optimasi bertujuan untuk mendapatkan model kombinasi terbaik berdasarkan persamaan matematika respon yang diinginkan. Pemilihan formula optimal, didasarkan atas nilai desirability mendekati 1. Desirability memiliki kisaran antara 0-1, dipilih yang mendekati 1 karena merupakan kombinasi formula paling optimal. Hasil optimasi yang diperoleh, hanya terdapat 1 formula optimal yang memiliki desirability mendekati (Tabel 5).

Tabel 5. Hasil Formula Optimum Berdasarkan Design Expert formula masker gel peel -off ekstrak daging buah labu kuning (Cucurbita maxima D).

\begin{tabular}{ccccccccc}
\hline $\begin{array}{c}\text { PVA } \\
(\mathbf{g})\end{array}$ & $\begin{array}{c}\text { Carbo } \\
\text { mer } \\
(\mathbf{g})\end{array}$ & $\begin{array}{c}\text { Propilengli } \\
\text { kol }(\mathbf{g})\end{array}$ & $\begin{array}{c}\text { Daya } \\
\text { Sebar } \\
(\mathbf{c m})\end{array}$ & $\begin{array}{c}\text { Waktu } \\
\text { Kering } \\
(\mathbf{m e n i t})\end{array}$ & $\begin{array}{l}\text { Viskositas } \\
(\mathbf{c p s})\end{array}$ & pH & $\begin{array}{c}\text { Desirabi } \\
\text { lity }\end{array}$ & Keterangan \\
\hline 3,955 & 0,575 & 5,470 & 5,2 & 9,99 & 9999 & 5,99 & 1 & Selected \\
\hline
\end{tabular}

Terdapat 1 solusi yang diberikan oleh software dengan komposisi PVA 3,95 gram, karbomer 0, 575gram dan propilenglikol 5,470 gram. Berdasarkan solusi tersebut, dilakukan uji konfirmasi dengan membuat sediaan sesuai dengan komposisi yang disarankan pada Tabel 5. Tujuan dilakukan uji konfirmasi ini untuk memastikan bahwa formula versi software memiliki kesamaan hasil respon sifat fisik yang sama atau mendekati dengan uji konfirmasi. Hasil uji konfirmasi dapat dilihat pada Tabel 6. 
Tabel 6. Hasil uji konfirmasi formula masker gel peel -off ekstrak daging buah labu kuning (Cucurbita maxima D) versi software.

\begin{tabular}{ccccccr}
\hline $\begin{array}{c}\text { PVA } \\
(\mathrm{g})\end{array}$ & $\begin{array}{c}\text { Carbomer } \\
(\mathrm{g})\end{array}$ & $\begin{array}{c}\text { Propilenglikol } \\
(\mathrm{g})\end{array}$ & $\begin{array}{c}\text { Daya } \\
\text { Sebar }(\mathbf{c m})\end{array}$ & $\begin{array}{c}\text { Waktu } \\
\text { Kering } \\
(\text { menit })\end{array}$ & $\begin{array}{c}\text { Viskositas } \\
(\mathbf{c p s})\end{array}$ & pH \\
\hline $\mathbf{3 , 9 5 1}$ & $\mathbf{0 , 5 7 6}$ & $\mathbf{5 , 4 7 3}$ & 5 & 6,10 & 9252 & 6 \\
\hline
\end{tabular}

Hasil uji konfirmasi (Tabel 6) yang dilakukan, menunjukkan respon pH, daya sebar dan viskositas memiliki hasil yang tidak jauh beda dengan solusi berdasarkan software. Respon waktu kering memiliki perbedaan dengan rentang cukup lama. Pada solusi yang diberikan oleh software, komposisi basis tersebut akan memberikan waktu kering selama 10 menit. Waktu kering pada uji konfirmasi sediaan tersebut lebih pendek yaitu diperoleh hasil sekitar 6 menit. Hasil analisis menggunakan t-test (Tabel 7) terhadap formula optimal menggunakan design expert dan uji konfirmasi, menunjukkan tidak berbeda bermakna $(p=0,388>0,5)$. Parameter respon sifat fisik yang dihasilkan tersebut telah sesuai dengan standar yang dipersyaratkan.

Tabel 7. Hasil uji $\mathrm{T}$ hasil konfirmasi formula masker gel peel -off ekstrak daging buah labu kuning (Cucurbita maxima D) versi software.

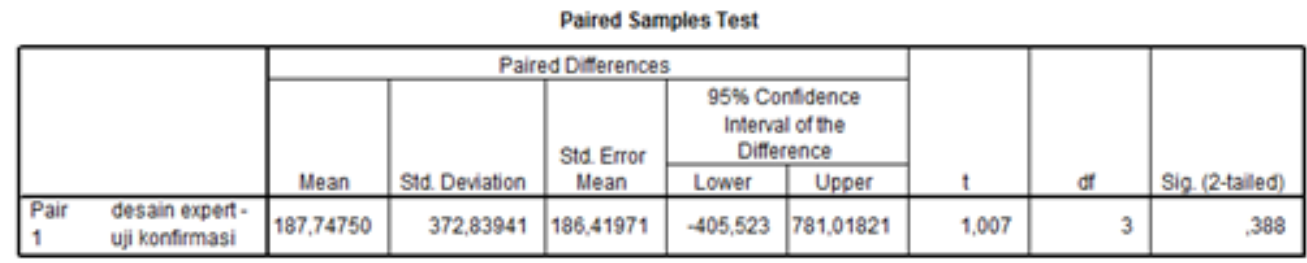

Pada penelitian sebelumnya tentang masker peel-off dari ekstrak biji labu kuning, menggunakan optimasi komposisi basis HPMC dan PVA, menghasilkan sifat fisik yang kurang sesuai. Waktu kering yang diperoleh melebihi standar yang ditentukan yaitu lebih dari 30 menit (Sunnah et al,, 2018). Penelitian lain yang membandingkan tentang stabilitas fisik sediaan krim dan masker gel peel-off ekstrak biji labu kuning, telah menghasilkan stabilitas fisik sesuai standar, (Sunnah, et al,2019). Viskositas sediaan masker gel peel-off, dalam penyimpanan selama 1 bulan, berada pada rentang $4000 \mathrm{cps}$, dengan daya sebar sesuai rentang yang dipersyaratkan $(5-7 \mathrm{~cm})$ dan $\mathrm{pH}$ masker gel peel-off di bawah 6,5. Hanya waktu kering yang dihasilkan belum maksimal, tetapi dengan perubahan formula dari HPMC dan PVA menjadi PVA, propilenglikol dan karbomer, mampu menurunkan waktu kering sediaan tanpa mengubah parameter stabilitas fisik yang lain. Formula basis sangat mempengaruhi stabilitas fisik sediaan. Pengubahan formula menggunakan optimasi komposisi basis yang baru yaitu PVA, propilenglikol dan karbomer, ternyata menghasilkan sifat fisik yang jauh 
lebih baik yaitu $\mathrm{pH}$, daya sebar, waktu kering, viskositas dan sentrifugasi sesuai dengan standar yang ditentukan.

\section{Kesimpulan}

Komposisi PVA (3,951 g), karbomer (0,576 g) dan propilenglikol (5,473 g) merupakan formula optimal masker gel peel off yang efektif karena memberikan respon sifat fisik berupa $\mathrm{pH}$, daya sebar, waktu kering dan viskositas sesuai dengan standar.

\section{Ucapan Terima kasih}

Terima kasih kepada Menristek Dikti atas Hibah Penelitian Dosen Pemula yang telah mendanai penelitian ini dan juga editor manuskrip serta pihak-pihak yang telah banyak membantu penelitian ini.

\section{Daftar Pustaka}

Abed, S. H. M., and Al-rashid, S. N. T. (2018). Study of the EffEcts of Nano-Particle Size on The Transmittanace of the CdTe Thin Film. Chalcogenide Letters, 15(5), 237-246.

Andini, T., Yusriadi, dan Yuliet. (2017). Optimasi Pembentuk Film Polivinil Alkohol dan Humektan Propilen Glikol pada Formula Masker Gel Peel off Sari Buah Labu Kuning (Cucurbita moschata Duchesne) sebagai Antioksidan. Galenika Journal of Pharmacy, 3(2), 165-173.

Beringhs, A. O., Rosa, J. M., Stulzer, H. K., Budal, R. M., and Sonaglio, D. (2013). Green Clay and Aloe Vera Peel-Off Facial Masks: Response Surface Methodology Applied to the Formulation Design. AAPS PharmSciTech, 14(1), 445-455.

Birck, C., Degoutin, S., Tabary, N., Miri, V., and Bacquet, M. (2014). New crosslinked cast films based on poly (vinyl alcohol): Preparation and physico-chemical properties. Express Polymer Letters, 8(12), 941-952.

Budiman, A., Kusuma, A., and Aulifa, D. (2017). Peel-off gel formulation from black mulberries

(Morus nigra) extract as. National Journal of Physiology, Pharmacy and Pharmacology, 7(9).

Daood, N. M., Jassim, Z. E., Gareeb, M. M., and Zeki, H. (2019). Studying the Effect of Different Gelling Agent on The Preparation and Characterization of Metronidazol as Topical Emulgel. Asian Journal of Pharmaceutical and Clinical Research, 12(3), 571577.

Dewi, C. C., dan Saptarini, N. M. (2016). Review Artikel: Hidroksi Propil Metil Selulosa dan Karbomer Serta Sifat Fisikokimianya Sebagai Gelling Agent. Farmaka, 14, 1-10.

Draelos, Z., and Thaman, L. (2006). Cosmetic Formulation of Skin Care Products. In Z. D. Draelos \& L. A. Thaman (Eds.). New York London: Taylor \& Francis.

Garg, A., Aggarwal, D., Garg, S., and Sigla, A. K. (2002). Spreading of Semisolid Formulation. Pharmaceutical Technology.

Goyal, R., Macri, L. K., Kaplan, H. M., and Kohn, J. (2016). Nanoparticles and nanofibers for topical drug delivery. J Control Release, 240, 77-92.

Jayronia, S. (2016). Design and Development of Peel-Off Mask Gel Formulation of Tretinoin For Acne Vulgaris. World Journal of Pharmacy and Pharmaceutical Sciences, 5(11), 
928-938.

Pal, R. S., Pal, Y., and Wal, P. (2017). In-House Preparation and Standardization of Herbal Face Pack. The Open Dermatology Journal, 11, 72-80.

Rahmawanty, D., Yulianti, N., dan Fitriana, M. (2015). Konsentrasi Gelatin Dan Gliserin Formulation and Evaluation Peel-Off Facial Mask Containing Quercetin with Variation Concentration of Gelatin and Gliserin. Media Farmasi, 12(1), 17-32.

Reveny, J., Nizliniwaty, and Umayah, R. (2016). Formulation of Peel-Off Mask from Ethanol Extract of Water Spinach Leaves as Anti Aging. International Journal of PharmTech Research, 9(12), 554-559.

Rikhana, I. (2018). Uji Antioksidan Ekstrak Daging Buah Labu Kuning (Cucurbita maxima D) Dengan Metode Metal Ion Chelating dan ABTS (2,2 Azinobis (3-Etilbenzotiazolin)6- Asam Sulfonat). Skripsi, Universitas Ngudi Waluyo.

Rowe, R. C., Sheskey, P. J., and Quinn, M. E. (Eds.). (2009). Handbook of Pharmaceutical Exipients (Sixth). London, UK: Pharmaceutical Press.

Salehi, B., Capanoglu, E., Adrar, N., Catalkaya, G., Shaheen, S., Ja, M. and Jugran, A. K. (2019). Cucurbits Plants: A Key Emphasis to Its Pharmacological Potential. Molecules, 24(1854), 1-23.

Sharma, A., Sharma, A. K., Chand, T., Khardiya, M., and Yadav, K. C. (2013). Antidiabetic and Antihyperlipidemic Activity of Cucurbita maxima Duchense (Pumpkin) Seeds on Streptozotocin Induced Diabetic Rats. Journal of Pharmacognosy and Phytochemistry, 1(6), 108-116.

Sulastri, A. dan Chaerunisaa, A. Y. (2016). Formulasi Masker Gel Peel Off Untuk Perawatan Kulit Wajah. Farmaka, 14(3), 17-26.

Sunnah, I., Mulasih, S., dan Erwiyani, A. (2018). Optimasi Formula Dan Stabilitas Senyawa Metabolit Ekstrak Biji Labu Kuning (Cucurbita maxima) Dalam Sediaan Gel Masker Peel-Off. Indonesian Journal of Pharmacy and Natural Product, ,1(1).

Sunnah, I., Mulasih., W.S., Mariani.S. dan Erwiyani.A.R. (2019). Uji Stabilitas Formula Optimal Sediaan Topikal Ekstrak Biji Labu Kuning (Cucurbita maxima), Avicenna Journal of Health Research. Vol 2 No 1. Maret 2019 (48 - 57).

Zhelsiana, D., Pangestuti, Y., Nabilla, F., Lestari, N., dan Erindyah, R. W. (2016). Formulasi Dan Evaluasi Sifat Fisik Masker Gel Peel- Off Lempung Bentonite. Universisty Research Colonium, 42-45.

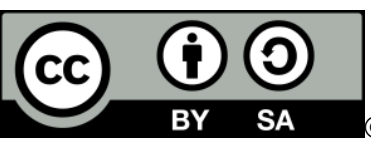

and conditions of the Creative Commons Attribution-ShareAlike 4.0 International (CC BY-SA 40) license (https://creativecommons.org/licenses/by-sa/4.0/). 